\title{
The Makings of Subaltern Subjects: Embodiment, Contradictory Consciousness, and Re-Hegemonization of Diaosi in China
}

Ngai-Ling Sum, Politics, Reader in Cultural Political Economy, Philosophy and Religion Department, Lancaster University, UK

*Email:n.sum@lancaster.ac.uk

ORCID iD: 0000-0002-4285-1351

Globalizations 28 July 2016 Online

http://dx.doi.org/10.1080/14747731.2016.1207936

\section{Abstract}

This article examines the emergence since 2011 of the 'Diaosi' (loser) identity among Chinese second generation migrant workers. This subjective identification of a new social category with little hope can be contrasted with the hopeful policy constructions of a strong China eager to promote the civilizing 'suzhi' (population quality) of its population nationally and internationally. Yet, as this article shows, in four steps, these phenomena are intertwined. First, it locates the emergence of this 'Diaosi' subject in the global and national dialectics of hope in China since the global financial crisis. In brief, while transnational policy and business actors constructed emerging markets, especially China, as objects of hope and sources of demand, the Chinese party-state had been hoping, since the 1990s, to build national strength and improve the sushi (quality) of its population. It was in this conjuncture that the Diaosi subject emerged. Second, drawing on neo-Foucauldian and neo-Gramscian scholarship, Diaosi marginality is related to the interaction among global capitalist production, the socialist market economy, continuous state domination via a 
household registration system (hukou), and the civilizing discourse of 'suzhi'. Focusing on the suzhi-hukou discourses and practices, it examines this ensemble as a biopolitical population management system that devalues migrant workers' lives and labour-power, obliging migrant workers to live and work in marginal conditions. A recent expression of this marginality is the making of the Diaosi subject position. Third, it shows how the Diaosi embody their multiplex loser identity and marginality affectively and expressively in their everyday demeanour. This signification system is characterized by a fragmented and 'contradictory consciousness' that combines resistance and resignation. Fourth, it examines recent efforts by state/corporate capital and the party-state to re-make and re-hegemonize Diaosi life in the name of consumption, civility and social stability. The article ends with remarks on the potential of (neo-)Gramscian insights on subalternity and subalterns for examining the complexities of marginal social categories such as the Diaosi and their embodiment of contradictory consciousness as well as the passive revolution and (re-)hegemonization that are involved.

Keywords: subaltern, Diaosi (loser), Gramsci, contradictory consciousness, rehegemonization

\section{Introduction}

This article examines the emergence of Chinese second-generation migrant workers who have been narrating and presenting themselves as 'Diaosi' (losers) since 2011. This self-identification of a new subject category with little hope can be juxtaposed to the concurrent policy constructions of China as an object of hope and strength eager 
to promote the civilizing 'suzhi' (population quality) of its people on (inter-)national levels. Yet these two phenomena are intertwined. This article has four sections. First, it locates the emergence of this 'Diaosi' subject in the dialectics of China as hope object since the global financial crisis. With the fear of recession in the US and Europe, emerging markets, especially China, have been constructed as objects of hope and sources of demand by transnational policy and business actors. This was articulated to China's own hope, evident since the 1990s, of building national strength, improving the 'suzhi' of its population, etc. This dialectics of hope was a central feature of the conjuncture in which the Diaosi subject emerged.

Second, drawing on neo-Foucauldian and neo-Gramscian scholarship, Diaosi marginality is analysed in terms of a co-governance by global capitalist production, the socialist market economy, continuous state domination via a household registration system (hukou), and the civilizing discourse of 'suzhi' (Pun 2005; Anagnost 2004; Yan 2008). Focusing on suzhi-hukou discourses and practices, the article examines them as a biopolitical population management mechanism in which less value is attached to migrant workers' lives and their labour-power receives lower wages. This sushi-hukou way of reproducing and managing inequalities means that migrants live in marginal conditions. Their marginality and subalternity are popularized through terms such as 'Dwelling Narrowness', 'ant tribe', and 'rat tribe' and, most recently, the Diaosi subject. Third, the article focuses more on the Diaosi's subjective embodiment of marginality in their everyday affective and expressive demeanour. Their experiences of exclusion, devaluation, unfulfilled consumer and romantic desires are central to the Diaosi-loser system of signification. This is far from consistent but involves what Gramsci terms 'contradictory consciousness', 
which comprises resistance and resignation. Fourth, it considers current efforts by state/corporate capital and the party-state to re-make and re-hegemonize Diaosi life in the name of consumption, civility, and social stability. The article ends with some neo-Gramscian remarks on the complexities and contradictory consciousness of marginal social categories, such as the Diaosi, and their openness to passive revolution and (re-)hegemonization.

\section{Financial Crisis and the Dialectics of China Hope}

The 2007 financial crisis in North America and Western Europe prompted fears of recession, rising debts and growing austerity. In response, transnational capitals sought new sites of demand and investment outside these regions. Emerging economies such as China were discursively constructed as dream sites that could contribute towards a global recovery (Sum 2013a). More specifically, until its own economic slowdown began in 2013, some (inter-)national policy-makers, think tanks, consultancy firms, bankers and economic journalists (e.g., Jaeger 2008; The Economist 2008; O'Neill 2013) represented the 'BRIC' economies, especially 'China', as global hegemonic 'hope' objects that could 'drive' global growth. Narratives such as 'China as the big BRIC', 'China as the second largest economy in the world', 'China has an 8\% GDP growth rate', 'China has a large middle-class consumer market', etc., were circulated transnationally (for dissenting views, see Chanos 2011; Block 2011; Pettis 2011). 
This hegemonic hope for global recovery is articulated to the Chinese Communist Party's hope for national glory through modernity (Yang and Lim 2010; Wang 2014), consumer citizenship (Hooper 2005; Ren 2013), and a neo-Confucian 'civility' (Bell 2010) conducive to 'social harmony' (later in terms of the 'China Dream'). Discourses on 'harmony' and 'suzhi' are prevalent in policy and everyday life since the 1990s (Anagnost 2004; Yan 2008; Jacka 2009). This approach to the art of governing has many manifestations but one particular expression is the discourse of middle-class 'suzhi' (Tomba 2009). This new class, comprising urban professionals and entrepreneurs, is constructed as 'suzhi' bearers. Their embodiment of population quality includes education, lifestyle, civil dispositions and the ability to capacitate themselves to appreciate the 'finer things in life' (Zhang 2010: 19; Ren 2011: 118-21; 2013: 34-44). This embodiment of 'suzhi' is especially pronounced in the middleclass consumer subjects whose actions are seen as stimulating the market without challenging the social order (Tomba 2009).

This co-identification of global China and its domestic middle class as hope objects was materially grounded in the rolling out of neoliberal measures/techniques in China under socialist state rule/guidance (Pow 2012: 38-39). Focusing on middleclass housing as symbolic of these changes, this middle-class hope for 'suzhi' life is intertwined with the desire for housing and homeownership in urban metropoles (Zhang 2010: 52-78). From a political economy perspective, this remaking of neoliberal personhood has depended on the marketization of land and housing markets from the 1990s onwards. This allowed for the institutionalization of land-use right market as well as the purchase of commercialized housing $(\mathrm{Wu}, \mathrm{Xu}$ and Yeh 2006: 50). It allows local governments (and their investment arms), land/property 
developers and state-owned banks to: (a) derive income from selling land-use rights, obtaining land-based loans, collateralizing land/property, and building/selling/speculating commodity housing for profit; and (b) pursue GDP growth rates (as GDPism) (Sum 2013b) that help cadres and those with connections rise up the bureaucratic ranks (Sum 2013a). This land- and property-based mode of accumulation and its related home consumption form one of the avenues in which the middle-class can demonstrate and realize wealth, status, 'suzhi' and exclusivity. 'Finer things in life' include home ownership, housing choice, home wealth generation, home décor, living in a gated community, quality family, quality husband/wife/children, etc. (Zhang 2010; Xiao 2010). The hope of creating a good life and social distinction is also reflected in the culture of marriage. The dream of 'living happily ever after' is to self-capacitate (with extended family support) to buy property, find a partner with matching qualities and improve on one's future 'sushi' and aspirations. There is a patriarchal folk saying of 'no car, no house, no bride' (Offheat China 2011) that aptly captures these aspirations as well as the unevenness of the consumer, marriage, love and intimacy markets in China.

This mode of land- and property-based accumulation was reinforced by the onset of the 2007 financial crisis. Worried about falling exports and rising unemployment, the Chinese leadership proposed a four-trillion Renminbi stimulus package in 2008 to reflate the economy (Naughton 2009). Up to 2011 this was coupled with US quantitative easing and related financial inflows to China (Cho and Rhee 2013).These policy measures were well-received by the international policy and business communities; but they have aggravated the deep-rooted central-local fiscal relations and local governments' efforts to appropriate and use land as collateral and 
to raise revenue. This intensified real estate inflation and fears of a 'property bubble' in China since 2009 (Powell 2010; Huang 2013). During the peak boom period from 2003 to 2012, property prices in major cities such as Beijing and Shanghai rose 3.65 and 3.41 times respectively ((Xianhuanet.com 2013. As for rents, the average unit rose three times in the same period (Baidu.com 2013). ${ }^{1}$ These bubble tendencies have accentuated the impact of uneven development on the material standards of urban dwellers and migrant workers labouring under poor conditions. Social unrest in terms of labour, land, and housing activism (Leung 2015; Hsing 2009; Zhang 2010) began to rise. Apart from activism, marginality was expressed through terms such as 'Dwelling Narrowness' (Yu 2011; Hung 2011), 'ant tribe' (Zhang 2013), and 'rat tribe' and, more recently, the Diaosi subject. The latter (self-)narrates as 'loser' subjects with 'little hope' (see below). Their 'lack of hope' is dialectically intertwined with the global hegemonic construction of China as a 'hope' object and its own modernity hope of national strength and a quality population.

\section{Exclusionary Practices in China's Biopolitical Population Management Mechanism: 'Hukou' and Suzhi'}

This dialectics of hope in the changing cultural political economy (Sum and Jessop 2013) of China is a central feature of the conjuncture in which the Diaosi subject emerged. Affected by rising housing prices, bad living conditions and unequal access to powerful connections, young migrant workers feel that they have been left behind by these neo-liberal commodification drives - made worse by the targeting of these workers in state-sponsored modes of devaluation. Drawing on neoFoucauldian scholarship (e.g., Miller and Rose 1990; Legg 2005), this section 
considers how the exclusionary household registration (hukou) and 'suzhi' systems (Pun 2005; Anagnost 2004; Kipnis 2006; Yan 2008; Jacka 2009) co-constitute China's bipolitical management mechanism to create cheaper migrant-labour bodies.

First, the purpose of the hukou system, established in the 1950s, has changed from preventing peasants from leaving their land to allowing them to 'float' into urban areas since the Deng era. Being a peasant in China is not an occupation but a status tied to one's birth (Zhang, N., 2014). Under the hukou system, rural migrants can move to cities, work and reside there but are not entitled to urban resources such as schooling and hospitals. This discourse of hukou targets the migrant population once they move to the cities. It operates as a governmental technology of classification and categorizes them as 'nongmin gong' (peasant workers). The policy space then excludes them from full entitlement to subsidized housing, education, medical care and welfare. This functional discrimination is deployed to deny migrants urban citizenship. Although the hukou system has undergone several reforms, it is still hard to convert from rural to urban status and, where it occurs, the privileges of the urban elite and China's costs of production are challenged in fundamental ways.

Since the 1990s, the exclusionary nature of hukou practices has been exacerbated by the modernity discourse of 'suzhi', which posits a hierarchy of civility. This not only denies the rural population access to urban resources but also devalues it as having 'lower quality'. Thus migrants are judged/labelled as transient and secondary. This technology of judgement assigns them a lower status more suitable for undesirable employment (.e.g., factory work, construction industry, low service sector, etc.) at lower wages (Zhang, F., 2014). These practices can be seen as part 
of a state-based biopolitical population management mechanism that marked migrants out as rural-inferior bodies to be assigned lower value in the urban environment. Once they migrate from the countryside, such exclusionary practices downgrade the value of their life as well as the market value of their labour-power. They become the source of cheap and flexible labour serving national development and China's insertion into global capitalism. These hukou-suzhi ways of constructing and governing inequalities mean that migrants must resort to living in marginal and sub-citizen conditions. Their sub-citizenship plights, together with the rising housing prices and rents, mean that industrial and service migrants must rely on employerprovided dormitories (Pun 2005), rent sub-standard accommodation in villages at the peripheries of towns (Wu, Webster, He and Liu 2010: 114-184), or reside in liminal spaces (e.g., balconies, roof tops or underground accommodation) in central urban conurbations of global cities. In Beijing, some migrants rented/shared small rooms at around US\$ 65 per month in 2014 in underground air raid shelters/storage spaces with communal toilets/kitchens and no natural light. About a million low-wage service workers (e.g., waiters, hairdressers, janitors, shop assistance, street peddlers, chefs, security guards, construction workers, etc.) occupied this subterranean housing in 2014 (Pulitzer Centre 2015). This facet of subaltern life is dubbed as 'rat tribe' and has been captured photographically by $\operatorname{Sim}(2015)$.

\section{Diaosi Embodiment of Marginality and Contradictory Consciousness}

These uneven macrosocial and biopolitical developments also affect their urban labouring and vulnerable body. Amongst many forms of expression, young migrants, who were users and makers of Internet pop culture and social media, increasingly self-narrate their marginality and subalternity as 'Diaosi' since the end of 2011. 
Young migrant workers feel that they have been left behind and express their marginality affectively through their self-identification as Diaosi. This making of the Diaosi subject can be captured by three inter-related moments with regards to bodily representations.

The first started in online fan clubs when they debated about a Chinese soccer player called Li Yi. This player once compared his football skills to the celebrated French player Thierry Henry (nicknamed 'Emperor Henry' in China). On this basis, his fans dubbed him 'Li Yi the emperor' (da di). This set the scene for the Diaosi online wordfest. Thus the term 'fans' was transliterated as 'fe-si' which means 'vermicelli' kind of noodle. When discussing their football hero, Li Yi's fans started to call themselves di-si (fans of the emperor); and, in return, their critics parodied 'di' into 'diao' which is a slang word for 'dick' (penis). Through this transposition from 'di' to 'diao', Li Yi's fans were no longer 'fans of emperor' but 'fans of penis' (diao-si).

This metonymic transposition via the body set the stage for the second moment of this collective wordplay. Li Yi's fans, instead of being offended, appropriated this as a self-mocking label within their proud fandom. They took pride in this derogatory label that resonated with subaltern migrants caught up in the dialectics of hope and frustration in China's development. This label soon went viral, escaping its original social base. Within two months after its coining in 2011 , it generated 41.1 million search results and 2.2 million blog posts on Google and China's Twitter-like Weibo respectively (Lui 2015). Young subalterns started to proclaim themselves as 'Diaosi' and there are all kinds of chat rooms and social media set up for this purpose (e.g., YY and $Q Q$ chats). 
A third moment began as the label gained popularity and Diaosi expressed their new system of signification in the public arena. They use their body to express exclusion, devaluation, frustration, hardship, social pain as well as unfulfilled consumer and romantic desires. They self-represent Diaosi marginality in corporeal terms and sceptically and ironically mapped themselves as 'poor, short and ugly' losers (Marquis and Yang 2013: 3). They visibilize themselves as coming from an underprivileged background earning a meagre wage, consuming little and having no social connections. ${ }^{2}$ Their meagre income/consumption and low social standing are coupled with the social-emotional side of living a devalued life of long working hours, poor housing, uncertain career, living away from family, guilt towards parents at home, and empty emotional life with little love/romance/intimacy. This emptiness and loneliness are often highlighted in Diaosi narrations of how they spent Valentine's Day, Christmas, festive seasons and the small hours of the night looking for Internet companions. Such affective discourses from the margins are not purely personal; they also express collective social experiences that are embedded in unequal access to state-based urban resources/status as well as inequalities generated by neoliberal policies in everyday economic and social life.

This everyday making of Diaosi subalternity is expressed through a binary trope that depicts two main body types based on their unequal access to power networks, consumption, love, romance and intimacy. First, male Diaosi self-deprecate as 'poor, short and ugly. With meagre income and unattractive physiques, they construct themselves as unable to impress girls by showering them with material gifts and/or charm. They have 'no house, no car and no bride/girlfriend' and spend most of their time at home, use cheap mobile phones, surf on the Internet, and play media games such as DotA. This male-oriented Diaosi construction has gradually spread to female 
subalterns, who also self-narrate as Diaosi. It was estimated that around 500 million people self-identify as Diaosi (Gao 2013). The popularity of this identity is partly reinforced by the mutual imbrication of the activities of the social media and their users. By February 2013, it was even widely circulated on these media (e.g., Weibo.com, sina.com, qq.com, tianya.cn; nbweekly.com, etc.) what constitute male and female Diaosi ‘standards' (see table 1).

Table 1 Mapping of Male and Female Diaosi Standards in 2013

\begin{tabular}{|c|c|}
\hline Typical Male Diaosi & Typical Female Diaosi \\
\hline $\begin{array}{l}\text { 1. Have less than } 1000 \text { RMB (USD } \\
\text { 150) cash on you } \\
\text { 2. Wear shoes costing less than } 800 \\
\text { RMB (USD 130) } \\
\text { 3. Have less than three girlfriends } \\
\text { before marriage } \\
\text { 4. Receive less than } 1000 \text { RMB } \\
\text { (USD 150) in annual bonuses } \\
\text { 5. Use pirated smartphones or those } \\
\text { under } 2000 \text { RMB (USD 300) } \\
\text { 6. No powerful friends } \\
\text { 7. Smoke cigarettes that cost less } \\
\text { than } 20 \text { RMB } \\
\text { 8. No car or use cars costing ess } \\
\text { than } 100 \text { 000 RMB (USD } 15000 \text { ) } \\
\text { 9. Drink only beer and cheap liquor } \\
\text { 10. Did not travel long-distance in the } \\
\text { last 3-5 years }\end{array}$ & $\begin{array}{l}\text { 1. Never bought bikinis } \\
\text { 2. Never wear bright nail vanish } \\
\text { 3. Never have a matching set of } \\
\text { lingerie } \\
\text { 4. Never wear high heels over } 5 \mathrm{~cm} \\
\text { 5. Have not changed hairstyle for the } \\
\text { last } 6 \text { months } \\
\text { 6. Have dieted for more than } 5 \\
\text { months } \\
\text { 7. Never guffaw in public } \\
\text { 8. Walk behind men } \\
\text { 9. Never look at or over-indulge in a } \\
\text { mirror } \\
\text { 10. Never remove body hair }\end{array}$ \\
\hline
\end{tabular}

(Source:

Weibo.com http://www.weibo.com/p/100808303d2e61b631b1f41af0887a9590ada2?p ids=Pl Third App 9\&feed sort=timeline\&feed filter=timeline\# rnd1428440459949 )

Second, this Diaosi subject is juxtaposed with another body type, characterized as: (a) Gaofushuai who are 'tall, rich and handsome'; and (b) 'princelings', who are 'second-generation officials'/'second-generation rich' with special party and family connections. In this Diaosi's system of signification, this second group are 'superior' 
and privileged with 'three treasures' (iPhone, sports car and designer watch) (Marquis and Yang 2013: 9) and also attract beautiful girls (see later). This juxtaposition of opposing body types constructs a Diaosi-Gaofushuai binary based on economic and social inequalities. Drawing on Scott's concept of 'hidden transcripts' (1990), this performative and narrative modern folklore about unevenness contains a mix of latent critique, self-mockery, self-protection, and selfentertainment (Yang, Tang and Wang 2015). It is a mundane way of protesting and relieving pressure in a system where exclusion is highly institutionalized and freedom of speech involves guerrilla tactics. The gaps between these two groups are further highlighted online via satirical cartoons, everyday photographs, TV shows, fantasy talks, etc. These include comparing their diverse modes of transport (bus vs. BMW), brands of smartphones (Nokia vs. Apple iPhone); eating places (side-street stores vs. expensive restaurants), and romantic encounters.

Apart from framing inequalities via body and consumption types, Diaosi also construct themselves as 'romantically unlucky' as their ideal girlfriends (named 'goddesses') are 'Bafumei' (fair-skinned, rich and pretty) and not 'Heimu'er' ('Black Fungus' women who are overly sexual experienced) (Li, Spotti and Kroon 2014). Given their meagre income, unattractive physique and the existence of a matchmaking industry catering mainly for rich men (Larmer 2013), Diasoi imagine that they will be out-competed by Gaofushuai/princelings and the Bafumei girls only belong to these rich and powerful men. This trope was vividly captured in a set of popular remarks first posted on ifeng.com:

'Diaosi have no money, no background, no future; they love playing $\operatorname{Dot} A, \ldots$ love 'moving bricks' [signifying themselves as workers in construction 
industry]. .... In front of Guofushuai, their fate is to kneel before them; gathering all their courage to chat up a 'goddess', what they get in return is a mocking 'hal-hal'3 .... They share low status, a boring life, a hopeless future, and an empty emotional life, they are not accepted by society.' (http://news.ifeng.com/opinion/special/diaosi/)

These ironic remarks reveal the subaltern-Diaosi common sense that contains a mix of precarious life with little money and no background; the self-mockery of a fate with no future/hope; the emotional emptiness of being shunned/mocked by 'goddesses', the latent hostility towards social elitism embodied by Gaofushuai and princelings; and the despair of not being accepted; but these tropes are concurrently subordinated to the hegemonic norms of sexual stereotypes and the unfulfilled dream of consumerism and entrepreneurialism for socio-economic advancement. Such ironic identities (Szablewicz 2014: 268) and contradictory consciousness (à laGramsci) involves self-deprecating critiques towards social inequalities but also submitting to the seduction of neoliberal consumerism and entrepreneurialism.

\section{Re-Hegemonization of Diaosi's Contradictory Consciousness}

This contradictory consciousness could be developed into a more critical consciousness and/or be re-hegemonized by dominant forces to provide new hope. As the Diaosi identity becomes more popular, celebrities - especially youth icon bloggers and technology entrepreneurs - begin to appropriate this identity (Gu 2014). In addition, it seems that Diaosi identity is partly being mainstreamed and rehegemonized in two ways. 
First, with the fall in GDP growth rate from 8 to $7.5 \%$ and an official anti-corruption campaign, (trans-)national capitals are looking afresh at the subaltern-Diaosi as a consumer market that could compensate for falling demand in the luxury goods market Thus a popular article first posted on the US-based Tea Leaf Nation highlighted that 'while the high-end market is weak, the Diaosi market prospects are bright (Zhang and Barreda 2013). This article was translated and re-posted on numerous Chinese business websites (e.g. business.sohu.com) and was widely regarded as the first Diaosi market report. Riding on this Diaosi tide, Gu (2014) from Wall Street Journal further mapped them as a consumer group as follows:

'What they lack in spending power compared with Western teens or rich Chinese, diaosi make up for in sheer numbers. Some of China's most successful companies, including Tencent Holdings Ltd., Alibaba Group and YY.com, have built multibillion-dollar businesses targeting them.' (Source: Wall Street Journal, 13 Feb 2013)

In short, they are re-evaluated by (trans-)national capital as a specific target consumer group with unfulfilled dreams of being Gaofushuai. Within China, the cultural industries wasted no time in capturing the Diaosi subject via mobile-phone games such as 'Diaosi Spring', Diaosi fictions/love music, and Sohu's TV drama on 'Diaosi Man'. Other creative Internet-based groups such as Alibaba, YY.com and Tencent Holdings Ltd. have designed different virtual products and pleasurable experiences to capitalize on their desires for counter-attack, wealth, consumption, enjoyment, entertainment and companionship/love/romance/sex.

In Diaosi's mode of signification, 'counter-attack' is a term borrowed from online war games where the losing side regains control and finally wins. Transposing this online 
imagery to the Diaosi-Gaofushuai relationship, counter-attack becomes a way to catch up with Gaofushuai in material terms. For example, some financial websites (e.g. yunxindai.com) urge Diaosi to launch 'beautiful counter-attacks' by buying eople-to-people (P2P) products targeting lower-income groups (see table 2). Their starting point could be as low as RMB 100. Once they subscribe, they are said to be 'investors' and destined to catch up with Gaofushuai in terms of their possession of wealth management products. Thus framed, 'counter-attack' is not an act of resistance towards structural inequalities; rather it is a hope-based selfresponsibilizing technology (Foucault 1988) to encourage them to constitute themselves as 'investors' and to work on themselves to improve their conditions in an imagined 'P-2-P' environment. It thus confirms individualized consumption and competitive entrepreneurialism oriented to sushi improvement rather than challenging them. These products are appropriated differently with many joining the ranks of the millions of users who generate substantial revenues for the providers (e.g. see table 2); whilst many others are cautious and, in some cases, financiallyliterate Diaosi offer critical advice through websites such as diaosibaoliao.cc and p2peye.com.

The acts of incorporation of Diaosi into the circuit of consumer and financial capitalism take other forms too. Retail and cultural industries draw them into their orbits by providing fun, pleasure and entertainment to their suffering bodies. For example, China's largest online shopping site, Alibaba's Taobao, created a Diaosi Fashion Club selling goods based on value, quality and fun. Concurrently, global mid-range fashion chains such as Zara and H\&M are also attracting this group of online consumers. The German car magazine, AutoBild, has announced three 'cheap branded cars' to target the Diaosi market (Zhuayoukong.com 2014). 
China's cultural-entertainment industry is also joining the Diaosi market by providing pleasurable group entertainment as 'cure' of loneliness. For example, the YY.com and 9158 are video-based networks. They feature virtual gift systems in which performers can earn credits through activities such as providing chat shows conducted by cute/sexy girls, karaoke singing or conducting tutorial videos. Participants can convert these virtual credits into real cash. This kind of affordable entertainment allows Diaosi to act out Gaofushuai-liked lifestyle and even dating fantasies. The QZone, which is run by QQ.com, is popular as migrants can use a mobile phone (and not computer) to access the Internet. It is free but charges for value-added services such as online games, avatar-based social networks with their own currency and products, and a virtual pet portal. On average, users spend about USD 20 per month on these products (see table 4). These sites are popular ways of keeping in touch with families/friends and their services/products are heavily used, possibly as 'cure' for loneliness in their devalued life.

Table 2 Major Internet-Based Groups and their Diaosi-Targeted

Sites and Products

\begin{tabular}{|c|c|c|}
\hline $\begin{array}{c}\text { Name of } \\
\text { Corporations }\end{array}$ & Nature of Sites and Products & Sales and User Volumes \\
\hline $\begin{array}{l}\text { Alibaba } \\
\text { Group }\end{array}$ & $\begin{array}{l}\text { Taobao } \\
-\quad \text { On-line shopping } \\
-\quad \text { Diaosi Fashion Club for } \\
\text { clothing and accessories } \\
- \text { Hosting Zara goods } \\
- \text { Single's Day for shopping } \\
\\
\text { Yu'ebao } \\
\text { - P2P money-market fund } \\
\text { - } \text { started since } 2013 \\
\text { - Users can start with RMB } 1 \\
\text { Offer higher interest rates }\end{array}$ & $\begin{array}{l}\text { - Single's Day sales volume } \\
\text { - } \quad \text { RMB } 35 \text { billion (USD } \\
5.7 \text { billion) } 2013 \\
-\quad \text { RMB } 19.1 \text { billion (USD } \\
3.1 \text { billion) } 2012 \\
-\quad \text { RMB } 5.2 \text { billion (UDS } \\
0.8 \text { billion) } 2011 \\
\text { - RMB } 554 \text { million (USD } 90 \\
\text { billion) in assets and } 81 \\
\text { million investors in } 2014\end{array}$ \\
\hline
\end{tabular}




\begin{tabular}{|c|c|c|}
\hline & $\begin{array}{l}\text { and instant liquidity } \\
-\quad \text { Mainly small clients with an } \\
\text { average deposit of RMB } \\
3300 \text { (USD 532) } \\
-\quad \text { Aggregated amount then } \\
\text { invest in Zenglibao money- } \\
\text { market fund run by Tianhong } \\
\text { (a Tianjin-based private-run } \\
\text { asset management firm) }\end{array}$ & \\
\hline YY.com & $\begin{array}{l}\text { - Social communication platform } \\
\text { - Provide group video sessions on } \\
\text { concerts, education, fashion, } \\
\text { sports and personal finance } \\
\text { - Sessions are hosted by stars } \\
\text { and can be rewarded by paying } \\
\text { for their virtual gifts (e.g. lollipop; } \\
\text { flowers) - a way of living the } \\
\text { imagined life of Gaofushuai } \\
\text { - Virtual dating service }\end{array}$ & $\begin{array}{l}\text { - } 310 \text { million registered } \\
\text { users and } 60 \text { million } \\
\text { monthly active users } \\
\text { - Active users spend on } \\
\text { average RMB 200-300 } \\
\text { (USD 32-48) per month }\end{array}$ \\
\hline $\begin{array}{l}\text { Tencent } \\
\text { Holdings } \\
\text { Ltd.'s } \\
\text { QQ.com }\end{array}$ & $\begin{array}{l}\text { Q QZone } \\
\text { - Social messaging service } \\
\text { and e-commerce } \\
\text { - Provide online/mobile-phone } \\
\text { games with cute/sexy girls } \\
\text { - Sell virtual goods (e.g. funny } \\
\text { images, pets, clothing and } \\
\text { accessories to customize } \\
\text { online avatars, etc.) }\end{array}$ & $\begin{array}{l}89 \text { million customers spent on } \\
\text { average USD } 20 \text { each per } \\
\text { month }\end{array}$ \\
\hline
\end{tabular}

(Source: Author's own compilation based on information on the three corporate websites)

Second, complementing this capitalist subsumption of the Diaosi identity (in other words, its re-hegemonization) is the re-assertion of party-state leadership over their contradictory common sense. Diaosi's spontaneous critiques towards social inequalities and self-mocking 'subversive laughter' have not gone unnoticed by those in power. This creative use of slang and body tropes captures the social pain, 
frustration and exclusion of the subaltern migrants. It also touches and highlights some political sore points with potentials to challenge existing power configurations. Recognizing such potentials, there are tendencies since March 2013 to disrupt, depoliticize and re-hegemonize this contradictory identity to become more consistent with the 'socialist spiritual civilization', 'improve suzhi', 'social stability' and, more recently, the 'China Dream'. Cultural actors such as linguists and film directors spearheaded this process of de-politicization via a civilizing mission. For some linguists, Diaosi's insinuation of the 'male genitalia' was regarded as 'rude' and 'vulgar'. More specifically, Hao Mingkam, a prominent linguist, a party member and founder of the influential Language Scrutiny book series, considered it as linguistically corrupted and too crude and uncivilized for public consumption. In his explanation for why the term Diaosi failed to make it into the 2012 Ten Most Popular Phrases in China, he stated that:

'... the extensive use of these words may allow some people to become psychologically and morally shameless; they think they can say anything. If a person uses vulgar language, his/her behaviour is far from being civilized' (culture.people.com.cn 2013)

In the same period, this civilizing mission was echoed by Feng Xiaogang, who is a commercially-successful film director/writer/actor. He claimed that he had difficulties in explaining Diaosi to his counterparts abroad. In his microblog, he recorded that this identity is not so much self-deprecating as 'self-destructive' and even 'brainless' (Chinanews.com 2013). This piece was forwarded tens of thousands of time. This has attracted agreement from Hao, the linguist, but this disruption generated 
resentments from within the Diaosi community (Sina.com 2013). Nonetheless, language and identity monitors of this kind continue to scrutinize and even sanitize the term by morphing it from its original version of Diaosi (meaning 'fans of penis') to a homonym of 'Dil-si' (meaning 'hanging wire'). Major websites such as Wikipedia (in Chinese) and Baidu even posed these two terms as being interchangeable with some even claiming that 'Dil-si' is more suitable for 'female Diaosi'. This focus on the sanitization of its scatological aspects (Yang, Tang and Wang 2014: 11) depoliticizes the social claims of Diaosi and weakens its critical edge. By the end of December 2014, the official presses also jointed in this civilizing mission. Official newspapers were posting critiques of Diaosi and their identity. On 2 December 2014, the People's Daily posted an article on 'Assessing Diaosi: When will Self-Deprecation End? This column highlighted that Diaosi is a self-denigrating label and its '.... cultures neither allow young people to be more independent nor transmit a more positive force to the society'. It 'should be denounced and abandoned, because it can cause serious harm to the spirit of youth' (wenweipo.com 2014). This piece was reprinted in other official newspapers such as China Youth Daily. These ways of monitoring and civilizing the Diaosi identity do not destroy critical consciousness but affect how its contradictory character is played out online in representational struggles.

This marginality is rejected by some subalterns and accepted by others. Some indulge in consumption and/or seek pleasure from the culture industries; others live in hope and assume personal responsibility to fulfill these entrepreneurialconsumerist dreams by improving 'suzhi', obtaining better qualifications, finding good jobs, meeting good marriage partners, and moving over-ground to more comfortable housing. These entrepreneurial self-hopes coexist with experiences of social 
inequalities, suffering bodies, self-mocking irony, frustrated sexuality, and hopeless future as part of their system of signification. This system is by no means consistent or coherent. It contains 'contradictory consciousness' and fragmentation (Crehan 2002: 191-193). The resulting political struggle is embedded in the contradictory ensemble of state-mediated capitalist-consumerist social relations that produce hope, devalued life, marginality and exploitation in China's cultural political economy. Such contradictory locations are reflected in a common sense that contains hegemonic forms of thinking as well as modes of critical insight. It interlaces agreement with the dominant consumerist/entrepreneurial ideology and precariousness, loneliness, self-mockery, frustrations and latent critical thinking as part of the subaltern conditions and languages.

\section{Two Sets of Concluding Remarks}

This article ends with two sets of remarks. First, regarding the Diaosi, it examines the dialectical intertwining of a loser/little hope subject with the global imagination of China as a 'hope' object since the financial crisis. This is the conjuncture in which the Diaosi subject emerged. Their marginality is co-governed by global capitalist production, the land- and property-based mode of accumulation, and continuous state domination via a hukou-suzhi biopolitical population management policy mechanism. With increasing inequalities and the making of a devalued life, younger second generation workers self-narrate as Diaosi and express such identity affectively. They embody their marginality via a body discourse that builds on the everyday unevenness regarding power networks, consumption, marriage, love and intimacy. This self-representational struggle of Diaosi is fragmented and they remain at best a 'class against the dominant order' rather than becoming, as a primarily 
class-theoretical analysis might anticipate, a unified class for itself that could effectively resist hegemony/domination. Indeed, at the time of writing, dominant market actors are providing consumer and entrepreneurial hope and state forces are seeking to remake, rehegemonize and disrupt the Diaosi subject with variable resonance. From a Gramscian viewpoint, it is worth asking whether the fragments of Diaosi could create an autonomous sphere of action that would enable them to overcome subalternity in the absence of the full consciousness of their alleged class identity and interests?

Second, by asking these questions inspired by neo-Gramscian insights, this paper has also addressed labour/subaltern studies on China. Some Marxist/Weberian scholars sought to understand second-generation migrant workers in terms of their class position and consciousness (e.g. Chan and Pun 2009; Leung and Pun 2009; Chan and Seldon 2013; Chan and Sui 2012: 79-160). These arguments are often linear. They assume that conditions of exploitation will either lead to proletarianization and identification with the working class or, where this is not fully developed, it is explained in Weberian terms concerned with limits on organizational and/or representational capacities. Conversely, those interested in the subaltern consciousness of migrant labour often focus on their cultural communicative practices (e.g., new media, urban cinemas and literature) and their speaker-abilities (e.g. Sun 2014; Pun 2005; Yan 2008). Inspired by first-generation Indian subaltern studies, especially Spivak, they hardly mentioned Gramsci, who discussed the subaltern in Notebook 25 in 1934. Indeed, this prompted Marcus Green (2002), a Gramscian subaltern scholar, to claim 'Gramsci Cannot Speak'. 
To give Gramsci a voice, this article suggests three (re-)entry points. First, examine the production of class consciousness not as automatic but as a culturally-mediated lived experience with diverse expressions (Zene 2011). The latter shifts attention from the working class (proletariat or sub-proletariat) to 'subaltern classes/groups' that encompass more components of society (Buttigieg 2013: 36). This allows an examination of different types of subaltern groups beyond their labouring identity (e.g., Diaosi's love life). Such marginal groups are fragmented with diverse expressions of critical consciousness and contradictory common sense (Ives and Green 2010: 304).

Second, neo-Gramscian insights also question the Marxist/Weberian focus on organizational and representational factors affecting the ability of labour to mobilize in China. For Green (2002: 19), improving these factors will not overcome group marginalization because this has deeper roots in exploitation and contradictions grounded in the overall ensemble of social relations with their various kinds of social exclusion (Ives and Green 2010: 305). Third, we can examine how subaltern agency is positioned between the politics of silence/invisibility dominated by elite discourses (cf. Spivak 1988) and the potentials of gaining their own voice and negotiating within and in relation to domination (cf. second generation subaltern studies, e.g. Green 2002: 18; Zene 2011: 96-98; Nielsen and Roy 2015: 1-5). ${ }^{4}$ Apart from focusing on the ability to speak, neo-Gramscians such as Green and Ives (2010: 302-307) stress the importance of 'language and imaginations from the bottom up' that allow for the visibilization of the varieties of subaltern agencies with diverse locations (Liguori 2015). Sun's work on Subaltern China (2014) is moving in this direction. However, if we seek to go beyond first-generation subaltern studies and return to the Gramscian tradition, we should also focus on language/imaginations/discourses (not only 
communication practices), contradictory consciousness of the subaltern as well as the concurrent processes of re-hegemonization that involve diverse realignments of subaltern knowledge/practices with hegemonic principles (Vahabzadeh 2008: 108).

In short, a neo-Gramscian entrypoint extends the examination of working-class consciousness to different types of subaltern classes/groups. The marginal and fragmentary elements of these groups have not become a class for itself; but exist as 'multiplicity' of elements of 'consciousness construction' (Modonesi 2014: 2; Green and Ives 2010: 292). In this regard, movement beyond first-generation subaltern studies discloses a range of subaltern experiences of subordination and insubordination and the affective languages and imaginations that contains critical and contradictory insights that can be re-grounded diversely in hegemonic principles. These constitute parts of the 'passive revolution' that depoliticizes and disrupts critical insights and alternative thinking among subaltern groups (Thomas 2009: 147).

\section{Endnotes}

${ }^{1}$ Worried about social instability, central government took steps between 2010 and 2013 to dampen the property market (e.g. tightening credit, raising deposits for purchase of new land to $50 \%$; restricting the purchase of second and third homes, etc.) with moderate effects upon housing prices and rents.

${ }^{2}$ The Market and Media Research Centre of Beijing University conducted a survey on the 2014 Living Conditions of Diaosi. Of 210,000 youths interviewed, more than $60 \%$ described themselves as Diaosi. This survey showed that they earned RMB 2917.7 (USD 479). From this, they spent RMB 500 (USD 81) on rent, RMB 39 (USD 
6) per day for 3 meals, RMB 1076 (USD 174) to send to parents, and RMB 500 (USD 81) on vacations.

${ }^{3}$ 'Hal-hal' is a popular Chinese term used by social networks and QQ groups. It has various meanings that range from communicating self-mockery through helplessness to don't know what to say. For details, see http://nx.shangdu.com/news/72-164630.html

${ }^{4}$ This article draws on but goes beyond first generation subaltern studies especially Spivak's post-Marxist-Derridean conception of the communicative process between subalterns and elites (Zene 2011: 94). Whereas Spivak examines this in terms of speech acts, this article directs attention to the contradictory consciousness and selfrepresentation of the subaltern and everyday struggles. This more MarxistGramscian analysis draws on Green (2002) and second generation subaltern scholars (e.g., Zene 2011; Nilsen and Roy 2015).

\section{Disclosure statement}

No potential conflict of interest was reported by the author.

\section{References}

Baidu.com (2013) Housing market observer: difficult to break the law of housing prices do not fall and rent can only rise', http://house.baidu.com/guangyuan/scan/0/5908764472327346505/(accessed 15 October 2015). 
Bell, D. (2010) China's New Confucianism: Politics and Everyday Life in a Changing Society (Princeton NJ: Princeton University Press).

Buttigieg, J. (2013) Subaltern social groups in Antonio Gramsci's Prison Notebooks, in C. Zene (ed.) The Political Philosophies of Antonio Gramsci and B.R. Ambedkar, Abington (London: Routledge), pp. 35-42.

Chan, A. and Siu, K. (2012) Chinese migrant workers: factors constraining the emergence of class consciousness, in B. Carrillo and D. Goodman (eds) China's Peasants and Workers: Changing Class Identities (Cheltenham: Edward Elgar Publishing), pp. 79-101.

Chan, C. and Pun, N. (2009) The making of a new working class? A study of collective actions of migrant workers in South China', China Quarterly, 198, pp. 287-303.

Chanos, J. (2011) Chanos Interview on 'China's property bubble is hitting the wall, Business Insiders, 21 September, http://www.businessinsider.com/chanos-chinaeuropean-kind-of-numbers-2011-9?IR=T (accessed 13 October 2015).

Chinanews.com (2013) Expert's assessment of Feng Xiaogang's comments on 'Diaosi': giving obscene connotations to buzzwords http://www.chinanews.com/cul/2013/03-06/4621699.shtml (accessed 14 October 2015) (in Chinese).

Cho, D. and Rhee, C. (2013) Effects of quantitative easing on Asia: capital flows and financial markets, Asian Development Bank Economics Working Paper Series, No. 350, June http://www.adb.org/sites/default/files/publication/30283/ewp350.pdf (accessed 10 October 2015).

Crehan, K. (2002) Gramsci, Culture and Anthropology (California: University of California Press). 
Culture.people.com.cn (2013) Linguist agrees with Feng Xiaogang view: the term 'Diaosi' should not be abused, http://culture.people.com.cn/n/2013/0308/c2221920717662.html (accessed 10 October 2015) (in Chinese).

Foucault, M. (1988) The political technology of individualism, in L. H. Martin et al. (eds) Technologies of the Self: A Seminar with Michel Foucault , (Amherst: University of Massachusetts Press), pp. 145-62.

Gao, J. (2013) 'The "Diaosi” social class: presage of impending social changes in China', June 25, 2013, http://www.ministryoftofu.com/2013/06/the-diaosi-socialclass-presage-of-impending-social-changes-in-china/ (accessed 14 October 2015).

Green, M. (2011) Gramsci cannot speak, in M. Green (ed.) Rethinking Marxism (Abington: Routledge), pp. 69-89.

Green, M. and Ives, P. (2010) Subalternity and language: overcoming the fragmentation of common sense; in P. Ives and R. Lacorte (eds) Gramsci, Language and Translation (Lanham: Lexington Books), pp. 289-309.

Gu, W. (2014) China's self-described losers play a winning role: consumer underclass may be where the real money is, Wall Street Journal, 13 February, http://www.wsj.com/articles/SB1000142405270230470380457938068340295872 4, (accessed 10 October 2015).

Hsing, Y-T., (2010) The Great Urban Transformation: Politics of Land and Property in China, Oxford: Oxford University Press.

Huang, Y. (2013) Lack of affordable housing threatens China's urban dream, China Dialogue, 20 September https://www.chinadialogue.net/article/show/single/en/6365-Lack-of-affordablehousing-threatens-China-s-urban-dream, (accessed 14 October 2015). 
Hung, R. (2011) The state and the market: Chinese TV serials on the case of Woju (Dwelling Narrowness), Boundary 2, 38, pp. 157-87.

Jager, M. (2008) 'BRIC as international investors: China in a class of its own', Deutsche Bank Research, Talking Point, http://www.slideshare.net/sonia bess/china-as-an-international-investor-in-a-class-of-its-own-presentation (accessed 12 March 2013).

Kipnis, A. (2006) Suzhi: a keyword approach, The China Quarterly, 186, pp. 295313.

Larmer, B. (2013) The price of marriage in China, The New York Times, 9 March, http://www.nytimes.com/2013/03/10/business/in-a-changing-china-newmatchmaking-markets.htm/? $\quad r=0$ (accessed 13 October 2015).

Legg, S. (2005) Foucault's population geographies: classifications, biopolitics and governmental spaces, Population, Space and Place, 11(3), pp. 137-56.

Leung, P.N. and Pun, N. (2009) The radicalization of the new Chinese working class: a case study of collective action in the gemstone industry, Third World Quarterly 30(3), pp. 551-65.

Leung, P. P. (2015) Labor Activists and the New Working Class in China (London: Palgrave).

Li, K., Spotti, M. and Kroon, S. (2014) An e-ethnography of Baifumei on the Baidu Tieba: investigating an emerging economy of identification online, Tilburg Papers in Culture Studies, No. 120, Tilburg University, https://www.tilburguniversity.edu/upload/c7982626-e1a6-40a8-93349fba945ac568_TPCS_120_Kunming-Spotti-Kroon.pdf (accessed 10 October 2015). 
Liguori, G. (2015) 'Conceptions of subalternity in Gramsci', in D. McNally (ed.) Antonio Gramsci (London: Palgrave), pp. 118-136.

Lui, J. (2015) China's disaffected Diaosi tribe, http://gbtimes.com/life/chinasdisaffected-diaosi-tribe (accessed 14 October 2015).

Marquis, C. and Z. Yang (2013) Diaosi: evolution of a Chinese meme, http://www.civilchina.org/2013/07/diaosi-evolution-of-a-chinese-meme/ (accessed 14 October 2014).

Miller, P. and Rose, N. (1990) Governing economic life, Economy and Society, 25(3), pp. 327-56.

Modonesi, M. (2014) Constructing the Political Subject: Subalternity, Antagonism, Autonomy (London: Pluto Press).

Nilsen, A. and Roy, S. (2015) Introduction, in A. Nilsen and S. Roy (eds) New Subaltern Politics: Reconceptualizing Subaltern Politics in Contemporary India (New Delhi: Cambridge University Press) pp. 1-10.

Offbeat China (2011) Leftover women in China speak their hearts out 'no car, no house, no bride', http://offbeatchina.com/leftover-women-in-china-speak-theirheart-out-no-house-no-car-no-bride (accessed 14 October 2015).

O'Neill, J. (2013) The Growth Map: Economic Opportunity in the BRICs and Beyond (London: Portfolio Penguin).

Pettis, M. (2011) China: no hard landing, but no solution, Financial Sense, http://www.financialsense.com/contributors/michael-pettis/2011/08/01/no-hardlanding-but-no-solution (accessed 14 October 2015).

Pow, C-P. (2009) Gated Communities in China: Class, Privilege and the Moral Politics of the Good Life (London: Palgrave). 
Pulitzer Centre (2015) Beijing's rate tribe, Pulitzer Centre of Crisis Reporting, http://pulitzercenter.org/project/asia-china-beijing-rat-tribe-migrant-workerspoverty-service-poor-housing (accessed 14 October 2015).

Pun, N. (2005) Made in China (Durham DC: Duke University Press).

Ren, H. (2013) The middle-class norm as responsible consumption in China's risk society, in A. Anagnost, A. Arai, and H. Ren (eds) Global Futures in East Asia: Youth, Nation, and the New Economy in Uncertain Times (Stanford: Stanford University Press), pp. 29-52.

Scott, J. (1992) Domination and the Arts of Resistance (New Haven: Yale University Press).

Sim, C.Y. (2015) Meet the million migrant workers living beneath Beijing's streets, Creativetimereports, 24 Jan, http://creativetimereports.org/2015/01/24/sim-chiyin-rat-tribe-beijing-underground-apartments/ (accessed 10 October 2015).

Sina.com (2013) Language experts agree with Feng Xiaogang: the Diaosi term should not be abused, http://ent.sina.com.cn/s/m/2013-0308/05393872334.shtml (accessed 14 October 2015) (in Chinese).

Spivak, Gayatri Chakravorty (1988) Can the subaltern speak?, in C. Nelson and L. Grossberg (eds) Marxism and the Interpretation of Culture (Urbana: University of Illinois Press), pp. 271-313.

Sum, N-L. (2013a) A cultural political economy of financial crisis: the turn to BRIC and the subalterns in China, Economy and Society, 42(4), pp. 543-70.

Sum, N-L. (2013b) Rethinking 'developmental state via cultural political economy: neoliberal developmentalism and the case of China', in Relocating Developmental States in their Transnational and Local Contexts, Conference Proceedings, SNU Asia Centre, National Seoul University, South Korea, 22-23 
August, 73-88, https://stateandregion.files.wordpress.com/2013/08/1st-

workshop-on-geo-political-economies-of-east-asia-full-proceedings.pdf (accessed 10 October 2015).

Sum, N-L. \& Jessop, B. (2013) Towards a cultural political economy (Cheltenham: Edward Elgar).

Sun, W. (2014) Subaltern China, Lanham: Rowman and Littlefield.

Szablewicz, M. (2014) The 'losers' of China's Internet: memes as 'structures of feeling' for disillusioned young netizens, China Information, 28(2), pp. 259-75.

Thomas, P. (2009) The Gramscian Moment (Leiden: Brill).

Tomba, L. (2009) Of quality, harmony, and community: civilization and the middle class in urban China, Positions, 17(3), pp. 591-616.

Vahabzadeh, P. (2008) The conditions of subalternity: reflections on subjectivity, experience and hegemony, http://socialiststudies.com/article/view/23782/17667 (accessed 14 October 2015).

Wenweipo.com (2014) People's Daily: Diaosi concept will damage the youth spirit, http://news.wenweipo.com/2014/12/02/IN1412020071.htm (accessed 10 October 2015) (in Chinese).

Wu, F., Webster, C., He, S., and Liu, Y. (2010) Urban Poverty in China, Cheltenham: Edward Elgar.

Wu, F., Xu, J. and Yeh, A.G.O. (2007) Urban Development in Post-Reform China: State, Market and Space, London: Routledge.

Xiao, H. (2010) Love as a capacity: the narrative of gendered development in Chinese-style divorce, Journal of Contemporary China, 19(66m), pp. 735-53. Xinhuanet.com (2013) Media report Shanghai and Beijing property prices rose by $500 \%$ and $365 \%$ respectively in a decade, 25 February, 
http://www.news.xinhuanet.com/fortune/2013-02-/25/c 124385598.htm,

(accessed 13 October 2015).

Yan, H. (2008) New Masters, New Servants, Durham: Duke University Press.

Yang, L. and Lim, C.K. (2010) Three waves of nationalism in contemporary China:

sources, themes, presentations and consequences, in E. Yeoh, (ed.) China in

Transition: Social Change in the Age of Reform (Kuala Lumpur: Institute of China Studies), pp. 461-86.

Yang, P., Tang, L. and Wang, X. (2015) Diaosi as infrapolitics: scatological tropes, identity-making and cultural intimacy on China's Internet, Media, Culture and Society, 37(2), pp. 197-214.

Yu, H. (2011) Dwelling narrowness: Chinese media and its disingenuous neoliberal logic, Continuum: Media and Cultural Studies, 25(1), pp, 33-46.

Zene, C. (2011) Self-Consciousness of the Dalits as 'Subalterns', in M. Green (ed.) Rethinking Marxism (London: Routledge), pp. 90-104.

Zhang, C. and D. Barreda (2013) Hip, young, and wired: China's 'Diaosi', in charts, Atlantic's Tea Leaf Nation, http://www.theatlantic.com/china/archive/2013/06/hipyoung-and-wired-chinas-diaosi-in-charts/277359/ (accessed 10 October 2015).

Zhang, F. (2014) China's Urbanization and the World Economy (Aldershot: Edward Elgar).

Zhang, L. (2010) In Search of Paradise: Middle-class Living in a Chinese Metropolis (Ithaca NY: Cornell University Press).

Zhang, N. (2014) Performing identities: women in rural-urban migration in contemporary China, Geoforum, 54, pp. 17-27.

Zhang, X. (2013) China's 'ant tribe' present social survival situation and personal financial advice, http://www.ccsenet.org/journal/index.php/ass/article/viewFile/24350/15405 (accessed 14 October 2015). 
Zhuayoukong.com (2014) Volkswagen will push three cheap brands, targeting the Chinese Diaosi market and plans to sell 500,000 cars, http://www.zhuayoukong.com/733454.html (accessed 14 October 2015) (in Chinese). 